\title{
HUBUNGAN SIKAP DALAM UPACARA BENDERA DENGAN RASA NASIONALISME DALAM PELAJARAN PPKn PADASISWA KELAS X SMK PELITA HAMPARAN PERAK TAHUN PELAJARAN 2018/2019
}

\author{
Muhammad Suhada ${ }^{1}$, Arsip Perangin-Angin ${ }^{2}$ \\ STKIP Budidaya Binjai
}

\begin{abstract}
ABSTRAK
Penelitian ini bertujuan untuk mengetahui hubungan upacara bendera dengan rasa nasionalisme pada mata pelajaran PPKn tauhn pelajaran 2018/2019. Penelitian ini dilakukan di SMK Pelita Bulu Cina. Adapun populasi dalam penelitian ini adalah kelas $X$ yang berjumlah 60 siswa. Penelitian ini menggunakan jenis penelitian kuantitatif. Instrumen penelitian yang digunakan adalah angket. Dengan adanya upacara bendera diharapkan cinta tanah air pada peserta didik dapat terbentuk dan menjadikan bangsa yang berakhlak mulia, bermoral, beretika, berbudaya, beradab berdasarkan Pancasila sehingga menjadikan bangsa yang berkarakter. Dapat disimpulkan bahwaHasil penelitian sebanyak 60 siswa yang mempunyai tingkat hubungan yang cukup baik atau sedang. Hal ini menunjukkan bahwa untuk memperoleh hubungan upacara bendera lebih dari cukup diperlukan rasa Nasionalisme yang tinggi. Dari hasil $t_{\text {hitung }}$ sebesar 2,45 > $\left.t_{\text {tabel }}=1,71\right)$. Yang berarti ada hubungan yang signifikan antara upacara bendera dengan rasa Nasionalisme siswa pada pelajaran PKn. Ini berarti bahwa hubungan upacara dengan nasionalisme yang baik selain adanya rasa nasionalisme yang cukup, baik dan sangat baik, juga didukung oleh adanya disiplin sekolah yang ketat dan konsisten, dan perilaku yang baik.
\end{abstract}

Kata kunci : Upacara bendera, nasionalisme

\section{PENDAHULUAN}

Pendidikan adalah usaha sadar yang dilakukan manusia untuk dapat mengembangkan potensi dirinya agar mampu bersaing secara global sehingga keberhasilan pembangunan dapat dicapai.Undang-undang No. 20 Tahun 2003 tentang Sistem Pendidikan Nasional menyatakan bahwa tujuan pendidikan untuk Mengembangkan kemampuan dan membentuk watak serta peradaban bangsa yang bermartabat dalam rangka mencerdaskan kehidupan bangsa bertujuan untuk berkembangnya potensi peserta didik agar bertakwa kepada Tuhan Yang Maha Esa, berakhlak mulia, sehat, berilmu, cakap, kreatif, mandiri, dan menjadi warganegara yang demokratis serta bertanggung jawab.

Untuk dapat menjalankan Undang-undang diatas pemerintah perlu meningkatkan pembangunan dibidang pendidikan baik dari segi kualitas maupun kuantitasnya. Peningkatan kualitas ini dapat dilakukan dengan meningkatkan sarana dan prasarana, tenaga pendidik serta mutu peserta didik. Penguasaan materi merupakan salah satu unsur penting yang harus diperhatikan oleh guru dan siswa dalam meningkatkan mutu pendidikan.

Pendidikan kewarganegaraan perlu diberikan kepada semua siswa untuk membentuk jiwa patriotik, rasa cinta tanah air dan semangat kebangsaan,Semangat perjuangan bangsa tersebut dilandasi oleh keimanan serta ketakwaan kepada Tuhan Yang Maha Esa dan keikhlasan untuk berkorban.

Landasan perjuangan tersebut merupakan nilai-nilai perjuangan bangsa Indonesia. "Semangat perjuangan bangsa merupakan kekuatan mental spiritual yang dapat melahirkan sikap dan prilaku heroik dan patriotik serta menumbuhkan kekuatan, kesanggupan, dan kemauan yang luar biasa. Semangat perjuangan bangsa inilah yang harus dimiliki oleh setiap warga Negara Kesatuan 
Republik Indonesia.Disamping itu, nilai-nilai perjuangan bangsa masih relevan dalam memecahkan setiap permasalahan dalam bermasyarakat, berbangsa dan bernegara.

Pendidikan Kewarganegaran sangat perlu diberikan kepada semua siswa karena Pendidikan Kewarganegaraan merupakan pintu untuk pembentukan sikap nasionalisme diri seseorang yang berlandaskan Pancasila dalam membangun bangsa yang semakin maju.

Dengan Pendidikan Kewarganegaraan seseorang dapat mengembangkan kemampuan berpikir logis, analitis, sistematis, kritis dan kreatif, serta kemampuan bekerja sama yang sangat dibutuhkan dalam kehidupan berbangsa dan bernegara. Kompetensi tersebut diperlukan agar siswa dapat memiliki kemampuan mengelola, dan memanfaatkan informasi untuk bertahan hidup pada keadaan yang selalu berubah, dan tidak pasti.

Peserta didik adalah generasi muda atau anak-anak bangsa yang sedang belajar dalam proses membentuk sikap diri sendiri untuk mengembangkan pengetahuan yang didapat dari para guru maupun teman seperjuangan dalam dunia pendidikan. Peserta didik disekolah kejuruan sebenarnya sudah mengenal materi yang erat kaitannya dengan pembentukan sikap nasionalisme yang sesuai dengan nilai pancasila.

Tetapi masih terdapat para siswa yang masih kurang mengetahui pentingnya upacara bendera dalam membentuk sikap nasionalisme terhadap kehidupan berbangsa dan bernegara. Oleh karena itu sekolah dan dewan guru masih tetap sangat perlu memberikan pelatihan yang akan menciptakan pemahaman, sikap dan perilaku dalam bentuk pelaksanaan upacara bendera.

Upacara bendera yang biasanya dilaksanakan setiap hari senin disekolah memiliki makna yang mendalam yang belum dipahami banyak oleh siswa Kelas X SMK Pelita Hamparan Perak, Kabupaten Deli Serdang. Makna upacara bendera yang masih dianggap rutinitas biasa.

Dalam kegiatan upacara bendera terdapat perilaku peserta didik yang biasa diketahui pada umumnya yaitu sikap Nasionalisme, dalam penelitian Pipit Widiatmaka: "Menjelaskan bahwa nasionalisme adalah suatu keadaan jiwa dan suatu kepercayaan, dianut oleh sejumlah besar manusia perseorangan sehingga mereka membentuk suatu kebangsaan.Hans Khon nasionalisme adalah suatu ikatan politik yang mengikat kesatuan masyarakat modern dan memberi pengabsahan terhadap klim (tuntutan) kekuasaan. Nasionalisme merupakan suatu kesatuan dari kelompok masyarakat yang ingin hidup bersama karena memiliki kesamaan tertentu dan memiliki perasaan cinta kepada tempat tinggalnya (bangsa).

Dalam penelitian Mey Riska Zayulate dkk juga mencantumkan pengertian nasionalisme : "Menurut Joseph Ernest Rehan : Nasionalisme adalah kemauan untuk bersatu tanpa paksaan dalam semangat persamaan dan kewarganegaraan. Menurut Ernest Gellenervia Nasionalisme adalah keseimbangan antara rasa nasional terhadap bangsa dengan kekuatan berpolitik.

Dalam penelitian Ernia Duwi Saputri, "Nasionalisme yang tercantum dalam Kamus Besar Bahasa Indonesia: "Nasionalisme adalah paham (ajaran) untuk mencintai bangsa dan Negara sendiri atau kesadaran keanggotaan dalam suatu bangsa yang secara potensial atau aktual bersama-sama mencapai, mempertahankan dan mengabdikan identitas, intregitas, kemakmuran dan kekuatan bangsa, semangat kebangsaan.

Nasionalisme merupakan suatu hal yang penting dan dapat memberikan dampak positif dimana pemahaman tersebut dapat mengakar kuat dan diharapkan akan menjadi prinsip dan kepribadian mereka yang nanti akan membentuk sikap sesuai dengan tujuan dari belajar itu sendiri. "Sehingga kita tetap memiliki wawasan dan kesadaran bernegara, sikap dan perilaku yang cinta tanah air, dan mengutamakan persatuan bangsa dalam rangka bela Negara demi tetap utuh dan tegaknya Negara Kesatuan Republik Indonesia.

\section{METODOLOGI PENELITIAN}

\section{Jenis Penelitian}

Jenis penelitian ini adalah Penelitian ini menggunakan metode pendekatan kuantitatif. Pengumpulan data dengan menggunakan teknik angket, dan Tes. Dengan populasi sebanyak 60 orang peserta didik dan 1 orang guru. Sampel dalam penelitian ini diambil dari jumlah populasi yaitu sebanyak 60 orang peserta didik.

\section{Instrumen Penelitian}

Adapun instrumen yang digunakan untuk memperoleh data dalam penelitian ini adalah angket.

\section{a. Angket}

Menurut Arikunto Angket adalah sejumlah pertanyaan tertulis yang digunakan untuk memperoleh informasi dari responden dalam arti 
laporan tentang pribadinya, atau hal-hal yang diketahui.

Jenis angket yang digunakan adalah jenis angket yang tertutup yaitu angket yang sudah disediakan jawabannya sehingga responden tinggal memilih. Tujuannya untuk mengetahui informasi dari responden.

Angket digunakan untuk mengetahui sikap siswa dalam upacara bendera, seperti baris-berbaris, menyanyikan lagu Nasional, Hormat kepada bendera merah putih, Hormat kepada Pembina upacara maupun pemimpin upacara. Angket yang diuji cobakan berjumlah 20 pertanyaan dengan 4 option jawaban sebagai berikut.

Tabel.Skor Alternatif Jawaban Angket

\begin{tabular}{lc}
\hline \multicolumn{2}{c}{ Pernyataan } \\
\hline Alternatif Jawaban & Skor \\
\hline Selalu (SL) & 4 \\
\hline Sering (SR) & 3 \\
\hline Kadang-kadang (KD) & 2 \\
\hline Tidak Pernah (TP) & 1 \\
\hline
\end{tabular}

b. Tes

Menurut Arikunto Tes adalah serentetan pertanyaan atau latihan serta alat lain yang digunakan untuk mengukur keterampilan, pengetahuan intelegensi, kemampuan atau bakat yang dimiliki oleh individu atau kelompok.

\section{PEMBAHASAN HASIL PENELITIAN}

\section{A. Deskripsi Hasil Penelitian}

Data-data yang diperlukan untuk analisis data dilakukan melalui pemberian angket kepada siswa, adapun jumlah sampel yang diambil dalam penelitian ini adalah sebanyak 60 sampel, yakni para siswa kelas X SMK Swasta Pelita Bulu Cina Tahun Pelajaran 2018/2019. Dari sejumlah sampel yang ada, akan dilihat hubungan sikap dalam upacara bendera dengan rasa Nasionalisme pada mata pelajaran PPKn.

Dengan demikian dari 60 sampel yang ada akan dilihat Hubungan antara dua variabel yang ada yaitu antara variabel Sikap dalam Upacara Bendera dan Rasa Nasionalisme dalam pelajaran PPKn. Sebelum data didapatkan seluruh siswa mengisi angket yang telah disediakan, dan tes untuk melihat rasa Nasionalisme siswa selama mengikuti proses belajar mengajar didalam kelas maupun dalam kegiatan upacara bendera.

Pada tahap awal, peneliti memberitahukan kepada siswa materi yang akan dipelajari, yaitu hubungan sikap dalam upacara bendera dengan rasa nasionalisme siswa dalam pelajaran PPKn, untuk melihat hubungan ini siswa ikut serta menjadi petugas upacara bendera maupun menjadi anggota pelaksana upacara bendera.

Pada tahap inti, setiap siswa diberikan soal angket sebanyak 20 soal. Setelah pengisian angket selesai, peneliti mengumpulkan lembar jawaban siswa untuk dinilai, kemudian peneliti menanyakan kepada siswa hal-hal apa saja yang kurang dimengerti mengenai upacara bendera maupun rasa nasionalisme, setelah peneliti menjelaskan pertanyaan para siswa, siswa langsung mencatat hal-hal yang kurang mereka ketahui.

Tahap akhir dalam penelitian ini adalah melihat perubahan siswa dalam kegiatan upacara selanjutnya, para siswa terlihat lebih aktip dari pada yang sebelumnya.

\section{B. Deskripsi Data Hasil Angket}

Berdasarkan data hasil sebaran angket yang dilakukan terhadap 60 siswa yang berisikan 4 Item pertanyaan mengenai penyajian data hubungan sikap dalam upacara bendera dengan rasa nasionalisme siswa dengan pemahaman, maka diketahui :

Nilai Tertinggi (NT) $=75$

Nilai Terendah (NR) $\quad=55$

Kategori (K) $=4$

Kemudian dicari kelas interval dengan rumus sebagai berikut:

$$
\begin{aligned}
& I=\frac{N T-N R}{K} \\
& I=\frac{75-55}{4} \\
& I=\frac{20}{4} \\
& I=5
\end{aligned}
$$

Berdasarkan skor yang diperoleh kemudian digolongkan menurut intervalnya sebagai berikut : 55-59 : Kategori Sangat Tidak Setuju

60-64 : Kategori Tidak Setuju

65-69 : Kategori Setuju

70-75 : Kategori Sangat Setuju

Berikut hasil distribusi frekuensi dari indikator tanggapan yang dipresentsikan menggunakan rumus presentase dan didapatkan hasil sebagai berikut :

$$
\begin{aligned}
& \mathrm{P}=\frac{\mathrm{F}}{\mathrm{N}} \times 100 \% \\
& \mathrm{P}=\frac{12}{60} \times 100 \%=20 \% \\
& \mathrm{P}=\frac{14}{60} \times 100 \%=23,33 \% \\
& \mathrm{P}=\frac{16}{60} \times 100 \%=26,66 \%
\end{aligned}
$$




$$
\mathrm{P}=\frac{18}{60} \times 100 \%=30 \%
$$
berikut ini

Hasil perhitungan dapat dilihat pada tabel

Tabel 4.1 Distribusi fr ekuensi penyajian data mengenai hubungan sikap dalam upacara bendera dengan ras nasionalisme siswa.

\begin{tabular}{|l|c|c|l|l|}
\hline No & Interval & Frekuensi & Presentase & Kategori \\
\hline 1. & $55-60$ & 12 & $20 \%$ & Sangat Tidak Setuju \\
\hline 2. & $61-65$ & 14 & $23,33 \%$ & Tidak Setuju \\
\hline 3. & $66-70$ & 16 & $26,66 \%$ & Setuju \\
\hline 4. & $71-75$ & 18 & $30 \%$ & Sangat se tuju \\
\hline
\end{tabular}

Pada tabel diatas dapat diketahui bahwa pada indicator tanggapan yang dituangkan dalam bentuk pernyataan sebanyak 12 responden $20 \%$, siswa masuk dalam kategori sangat tidak setuju. Sebanyak 14 responden 23,33\%, siswa masuk dalam kategori tidak setuju. Sebanyak 16 responden $26,66 \%$, siswa masuk dalam kategori setuju. Sebanyak 18 responden $30 \%$, siswa masuk dalam kategori sangat setuju.

Penulis untuk mengetahui hubungan upacara bendera dengan rasa Nasionalisme siswa dengan jumlah 60 orang siswa dengan banyaknya angket 20 item. Deskripsi data hasil angket sebagai berikut:

Tabel.hasil angket upacara bendera dengan rasa Nasionalisme

\begin{tabular}{ccc}
\hline Nilai (x) & Frekuensi (f) & Fx \\
\hline 55 & 11 & 605 \\
\hline 60 & 12 & 720 \\
\hline 65 & 11 & 715 \\
\hline 70 & 12 & 840 \\
\hline 75 & 14 & 1,050 \\
\hline Jumlah & 60 & 3,930 \\
\hline
\end{tabular}

Berdasarkan hasil yang didapat rata-rata hasil angket hubungan upacara bendera dengan rasa nasionalisme siswa sebesar 65,8 . Adapun diagram mengenai nilai angket akan digambarkan sebagai berikut sebagai deskripsi data yang didapatkan selama melakukan penelitian ini.
Diagram Batang 4.2 Jumlah Skor Angket

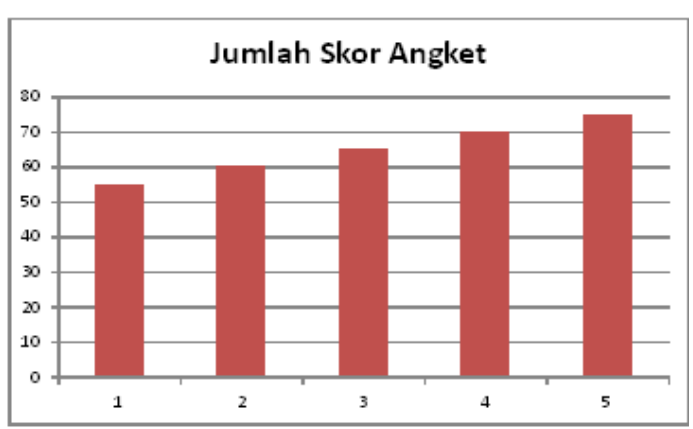

Keterangan : bahwa diagram batang mengenai skor angket ini menjelaskan bahwa dalam bentuk nilai angket sebesar 55 sebanyak 12 responden, siswa masuk dalam kategori sangat tidak setuju. Sebesar 60 sebanyak 14 responden, siswa masuk dalam kategori tidak setuju. Sebesar 65 Sebanyak 16 responden, siswa masuk dalam kategori setuju. Sebesar 70 Sebanyak 18 responden $30 \%$, siswa masuk dalam kategori sangat setuju.

\section{Validitas dan Reliabilitas}

Untuk mengetahui apakah dikatakan valid dan reliabilitas, maka peneliti melakukan suatu uji data. Untuk mengetahui valid atau tidaknya suatu angket. Maka Uji validitas ini dilakukan untuk 60 responden. Dan hasil yang diperoleh $r$ (hitung) kemudian dikonsultasikan dengan $\mathrm{r}$ tabel sebesar 0,388 dengan taraf signifikansi 0,05 atau (5\%), dan $\mathrm{N}=60$, bila $\mathrm{r}_{\text {hitung }}>\mathrm{r}_{\text {tabel }}$ maka faktor instrument dianggap valid, jika $r_{\text {hitung }}<r_{\text {tabel }}$ maka faktor instrument tersebut tidak valid.

Setelah data divaliditas selanjutnya dilakukan uji reliabilitas untuk mengetahui data tersebut dapat dipercaya. Dan hasil uji reliabilitas yang telah diperoleh kemudian dikonsultasikan dengan $\mathrm{r}$ tabel, dengan taraf signifikansi 0,05 atau (5\%), dengan $\mathrm{N}=60$, hasil dari $\mathrm{r}$ hitung 0,973 dan 60tabel 0, 388 sehingga $r$ hitung $>r$ tabel, maka instrument ini sudah reliabele.

\section{Pengujian Hipotesis}

Untuk menguji hipotesis penelitian ini, digunakan teknik korelasi product moment. Uji ini digunakan untuk melihat korelasi antara variabel $\mathrm{X}$ dengan variabel $\mathrm{Y}$ pada siswa kelas X SMK pelita bulu cina. Adapun hipotesis yang telah diajukan oleh peneliti sebelumnya adalah terdapat hubungan yang signifikan antara sikap dalam upacara bendera dengan rasa nasionalisme siswa.

Uji korelasi produt moment yang dilakukan peneliti berdasrkan kriteria pengujian yaitu jika $r_{\text {hitung }}>r_{\text {tabel }}$ maka terdapat korelasi yang signifikan antara variabel $X$ dan $Y$. namun jika $r_{\text {hitung }} \leq r_{\text {tabel }}$ maka tidak terdapat korelasi yang signifikan antara 
variabel $\mathrm{X}$ dan variabel $\mathrm{Y}$. dengan taraf signifikansi $=0,05$ dan $\mathrm{n} 60$.

Berdasarkan hasil perhitungan yang telah dilakukan dengan menggunakan uji statistik, diperoleh $\sum X=3757, \sum Y=3205, \sum X^{2}=325617$, $\sum \mathrm{Y}^{2}=237959$ dan $\sum \mathrm{XY}=275617$. Hasil perhitungan ini kemudian dimsukkan kedalam rumus hipotesis korelasi product moment agar bisa diketahui berapa besar koefisien korelasi antara variabel $\mathrm{X}$ dan variabel $\mathrm{Y}$. melalui perhitungan tersebut diperoleh hasil $r_{\mathrm{xy}}$ atau $\mathrm{r}_{\text {hitung }}=0,796$ dan 0,297 .

\section{E. Pembahasan Hasil Penelitian}

Langkah pertama yang dilakukan oleh peneliti daalam pelaksanaan penelitian ini, yaitu melakukan uji validitas dan uji reabilitas terhadap instrument angket yang digunakan dalam penelitian.

Langkah selanjutnya dalam penelitian ini, melakukan uji hipotesis dengan menggunakan rumus korelasi product moment. Dari hasil perhitungan rumus korelasi product moment menunjukkan bahwa $r_{\text {hitung }} \leq r_{\text {tabel }}$ maka $0,796 \geq$ 0,297 dapat disimpulkan bahwa hipotesis yang diajukan oleh peneliti diterima, yaitu terdapat hubungan sikap dalam upacara bendera dengan rasa nasionalisme SMK Pelita Bulu Cina.

Hasil penelitian dan dari hasil pengujian hipotesis menunjukkan bahwa hubungan upacara bendera dengan rasa Nasionalisme siswa kategori cukup atau sedang, hipotesis diatas dapat diterima mengingat bahwa upacara yang tertib dan aktip akan membantu siswa dalam meningkatkan semangat Nasionalisme siswa kelas x SNK swasta pelita bulu cina. Hasil penelitian juga menunjukkan bahwa upacara bendera siswa kelas $\mathrm{X}$ pada pelajaran PKn dalam kategori cukup.

Hasil penelitian sebanyak 60 siswa yang mempunyai tingkat hubungan yang cukup baik atau sedang. Hal ini menunjukkan bahwa untuk memperoleh hubungan upacara bendera lebih dari cukup diperlukan rasa Nasionalisme yang tinggi. Dari hasil $\mathrm{t}_{\text {hitung }}$ sebesar 2,45 $\left.>\mathrm{t}_{\text {tabel }}=1,71\right)$. Yang berarti ada hubungan yang signifikan antara upacara bendera dengan rasa Nasionalisme siswa pada pelajaran PKn. Ini berarti bahwa hubungan upacara dengan nasionalisme yang baik selain adanya rasa nasionalisme yang cukup, baik dan sangat baik, juga didukung oleh adanya disiplin sekolah yang ketat dan konsisten, dan perilaku yang baik.

\section{F. Keterbatasan Penelitian}

Setiap peneliti mempunyai kemampuan yang berbeda-beda, termasuk juga peneliti dalam melaksanakan penelitian ini masih ada keterbatasan. Di dalam penelitian ini terdapat beberapa keterbatasan antara lain :

1. Peneliti hanya menggunakan instrumen angket dalam mengukur rasa Nasionalisme, siswa dalam menjawab pertanyaan angket seringkali tidak sesuai dengan fakta yang sebenarnya.

2. hubungan upacara bendera dengan rasa nasionalisme siswa dalam penelitian ini kurang maksimal, karena rasa nasionalisme siswa terkadang berubah-ubah berdasarkan kondisi lingkungan yang tidak menentu.

\section{Kesimpulan}

Berdasarkan penelitian tentang Hubungan upacara bendera dengan Rasa Nasionalisme dalam pelajaran PKn pada siswa kelas X SMK Pelita bulu cina Perak Tahun Pelajaran 2018/2019. Peneliti mengambil kesimpulan sebagai berikut:

Bahwa dalam bentuk nilai angket sebesar 55 sebanyak 12 responden, siswa masuk dalam kategori sangat tidak setuju. Sebesar 60 sebanyak 14 responden, siswa masuk dalam kategori tidak setuju. Sebesar 65 Sebanyak 16 responden, siswa masuk dalam kategori setuju. Sebesar 70 Sebanyak 18 responden $30 \%$, siswa masuk dalam kategori sangat setuju.

Melalui upacara bendera yaitu dengan menanamkan rasa Nasionalisme, sehingga peserta didik dapat memahami upacara bendera dengan baik. hubungan upacara bendera dengan rasa Nasionalisme siswa kategori sedang, hipotesis diatas dapat diterima mengingat bahwa upacara yang tertib dan aktip akan membantu siswa dalam meningkatkan semangat Nasionalisme siswa kelas $\mathrm{x}$ SNK swasta pelita bulu cina. Hasil penelitian juga menunjukkan bahwa upacara bendera siswa kelas X SMK Pelita Bulu cina pada pelajaran PKn.

Dalam proses pembentukan karakter cinta tanah air melalui upacara bendera berjalan dengan baik. Akan tetapi, ada kendala dalam persiapan dan pelaksanaannya yaitu dari peserta didik maupun kesibukan pendidik yang melatih upacara bendera.

Dengan adanya upacara bendera diharapkan cinta tanah air pada peserta didik dapat terbentuk dan menjadikan bangsa yang berakhlak mulia, bermoral, beretika, berbudaya, beradab berdasarkan Pancasila sehingga menjadikan bangsa yang berkarakter. 


\section{B. Saran}

Berdasarkan kesimpulan di atas, peneliti memberikan saran sebagai berikut:

\section{Pendidik}

a. a.Pendidik lebih meningkatkan perhatiannya dalam pembentukan sikap cinta tanah air peserta didik berupa dukungan dalam upacara bendera maupun kegiatan lainnya.

b. Pendidik memberikan pemahaman kepada peserta didik mengenai rasa cinta tanah air melalui kegiatan upacara bendera maupun kegiatan lainnya.

c. Pendidik memberikan motivasi kepada peserta didik agar selalu menerapkan nilainilai cinta tanah air di dalam lingkungan sekolah maupun masyarakat.

\section{Peserta Didik}

a. Sebagai generasi muda penerus bangsa, peserta didik harus mengamalkan nilai-nilai pancasila yang dapat mewujudkan rasa cinta tanah air yang tinggi.

b. Harus ikut berpartisipasi dalam kepengurusan upacara bendera karena upacara bendera merupakan sarana pembelajaran untuk menanamkan sikap cinta tanah air.

c. Peserta didik diharapkan terus mengikuti dan terus melakukan kegiatan positif dengan aktif dan partisipatif dalam kegiatan upacara bendera maupun kegiatan lainnya dalam mengembangkan sikap cinta tanah air.

d. Mampu memahami dan menerapkan Tata Upacara Bendera di sekolah dengan benar, baik sebagai petugas maupun peserta upacara bendera.

\section{DAFTAR PUSTAKA}

Arikuto Suharsimi, 2006. Prosedur Penelitian Suatu Pendekatan Praktik, Jakarta: Rineka Cipta.

2006. Prosedur Penelitian Suatu Pendekatan Praktik, Jakarta: Rineka Cipta

2006. Prosedur Penelitian Suatu Pendekatan Praktik, Jakarta: Rineka Cipta

Aprian, An-Nissa, 2017. Pengaruh Living Values Education Program (LVEP) Terhadap Penanaman Karakter Nasionalisme Siswa SD Dalam Pelajaran Tematik, Jurnal Taman Cendikia,
Cahyono, 2016 Pengaruh Kedisiplinan Terhadap Peningkatan Prestasi Belajar Peserta Didik Pada Mata Pelajaran PKn diSMK Pasundan 1 Subang, Jurnal Pendidikan Guru Sekolah Dasar.

Daryono, M, dkk. 2008. Pengantar Pendidikan Pancasila dan Kewarganegaraan. Rineka Cipta.

Dimyati, Mudjiono, 2013. Belajar dan Pembelajaran. Jakarta, Rineka Cipta.

2013. Belajar dan Pembelajaran. Jakarta, Rineka Cipta.

Hakim, Lukman, Nul, 2014."Upacara Bendera Dan Nasionalisme, Pusat Pengkajian Pengolahan Data Dan Informasi,

Harsono, Sonny,2014/2015 Peningkatan Sikap Nasionalisme Melalui Pembelajaran Ips Dengan Menggunakan Metode Sosiodrama Pada Siswa Kelas V SD Negeri 3 Imogiri Bantul, Jurnal Pendidikan Kewarganegaraan, Universitas PGRI Yogyakarta,

Ihsan, 2014, Kecenderungan Global Dalam Proses Pembelajaran Pendidikan Pancasila dan Kewarganegaraan Disekolah". Jurnal Pancasila dan Kewarganegaraan.

Kaelan, H. Achmad Zubaidi. 2010. Pendidikan Kewarganegaraan. Paradigma, Yogyakarta

Mahmuda, Nurul, 2016, Sikap Santri Terhadap Kesehatan Produksi Remaja di Pondok Pesantren Putri Al Manaar Muhammadiyah I Pemalang”.

Permendikbud No. 23 Tahun 2015 tentang Penanaman Budi Pekerti

Pidarta, Made, 2009, Landasan Kependidikan : Stimulus Ilmu Pendidikan Bercorak Indonesia, Rineka Cipta, Jakarta.

Saputri, Emia Duwi, 2016. Peran Dosen Dalam Menumbuhkan Jiwa Nasionalisme Mahasiswa Program Studi Pendidikan Pancasila dan Kewarganegaraan IKIP PGRI Bojonegoro.Jurnal Media Prestasi

Sumarsono, S., dkk, 2001. 'pendidikan Kewarganegaraan, Jakarta: Gramedia Pustaka Utama, 
2001. Pendidikan Kewarganegaraan, Jakarta: Gramedia Pustaka Utama.

"Undang-Undang Dasar Negara Republik Indonesia Tahun 1945.

Widiatmaka,Pipit, 2016. Pembangunan Karakter Nasionalisme Peserta Didik Disekolah Berbasisi Agama Islam "Jurnal Pancasila dan Kewarganegaraan, Surakarta,

$\longrightarrow$ 2016. Pembangunan Karakter Nasionalisme Peserta Didik Disekolah Berbasisi Agama Islam “ Jurnal Pancasila dan Kewarganegaraan Surakarta,

Zayulate, Mey Riska, dkk, Persepsi Siswa Terhadap Pelaksanaan Upacara Bendera Dalam Pembentukan Sikap Nasionalime.Jurnal Pembentukan Sikap Nasionalisme.

Persepsi Siswa Terhadap Pelaksanaan Upacara Bendera Dalam Pembentukan Sikap Nasionalime.Jurnal Pembentukan Sikap Nasionalisme.

Dimyati, Mudjiono, 2013. Belajar dan Pembelajaran. Jakarta, Rineka Cipta. 